\title{
First record of the coloured righteye flounder, Poecilopsetta colorata (Teleostei: Poecilopsettidae) from the Sakalaves seamounts in the Mozambique Channel
}

Wei-Jen Chen ${ }^{1 *}$, Jhen-Nien Chen ${ }^{1}$, Eve-Julie Pernet ${ }^{2}$ and Karine Olu ${ }^{2}$

\begin{abstract}
Background: The coloured righteye flounder, Poecilopsetta colorata Günther, 1880 was previously known from the eastern Indian Ocean to the South China Sea and Indonesia. Here, a new record from the western Indian Ocean is reported.

Results: The new record is based on a specimen collected on the Sakalaves seamounts at $375 \mathrm{~m}$ in depth in the Mozambique Channel during a recent oceanographic survey. Four other teleost fish species including an uncommon ophidiid species, Neobythites somaliaensis Nielsen, 1995 were also collected on the same seamounts.

Conclusions: The presence of P. colorata in the Mozambique Channel suggests a broad and Indo-West Pacific wide distribution for this relatively rare deep-sea species. The sequence of the cytochrome oxidase subunit-I for the collected specimen is provided as a genetic reference for further DNA barcoding and systematic studies.

Keywords: Fishes, New record, Distribution, Western Indian Ocean, Mozambique Channel, Sakalaves seamounts, COI, PAMELA-MOZO1 cruise
\end{abstract}

\section{Background}

The bigeye flounders of the genus Poecilopsetta Günther, 1880 (Poecilopsettidae) (Sakamoto, 1984; Nelson, 2006) include 15 currently recognized species that inhabit the deep seas of the tropics (Munroe, 2015). Seven species of Poecliopsetta occur in the Indian Ocean ( $P$. albomaculata Norman, 1939, P. colorata Günther, 1880, P. natalensis Norman, 1931, P. macrocophala Hoshino, Amaoka and Last, 2001, P. normani Foroshchuk \& Fedorov, 1992, P. praelonga Alcock, 1894, P. vaynei Quéro et al., 1988, and P. zanzibarensis Norman, 1939) (Quéro et al., 1988; Hoshino, 2000; Guibord and Chapleau, 2001, 2002; Hoshino et al., 2001; Evseenko, 2004; Kawai and Amaoka, 2006; Kawai et al., 2010). To date, only three species ( $P$. natalensis, $P$. vaynei, and $P$. zanzibarensis) have been recorded from the Mozambique Channel in

\footnotetext{
* Correspondence: wjchen.actinops@gmail.com

${ }^{1}$ Institute of Oceanography, National Taiwan University, No.1 Sec. 4 Roosevelt Road, Taipei 10617, Taiwan

Full list of author information is available at the end of the article
}

the western Indian Ocean (Fischer and Bianchi, 1984; Quéro et al., 1988; Foroshchuk and Fedorov, 1992; Evseenko, 2004; Hensley, 1997). The coloured righteye flounder, P. colorata Günther, 1880, is a rare bathydemersal species living at depths of 214-800 m (Hensley, 1997; Evseenko, 2004). P. colorata is currently known from the eastern Indian Ocean to the South China Sea and Indonesia (Hensley, 1997; Evseenko, 2004).

The authors examined 55 fish specimens collected during the 32-day multi-disciplinary cruise (campaign: PAMELA-MOZ01) in 2014 of the R/V Atalante deployed by the French Oceanographic Fleet in the Mozambique Channel in the western Indian Ocean. Among them, one specimen was identified as $P$. colorata.

The purpose of the present work is to record this species in the ichthyofauna of the Mozambique Channel and provide a molecular sequence from a mitochondrial gene as the genetic reference for further DNA barcoding and systematic studies. 


\section{Methods}

The materials described in the present paper were collected during the cruise PAMELA-MOZ01 of the PAMELA project in 2014 conducted by the R/V Atalante (Olu, 2014) on the collection sites from three of the explored zones, the slope of the Glorieuses islands, the slope of the Mahajanga basin off Madagascar, and the Sakalaves seamounts on the southern Davie ridge (Fig. 1). The Warén dredge, NIWA seamount sledge and beam trawl were used for sampling at a total of eight sites. The geographic coordinates of the sites, depths, and methods for the deployments are listed in Table 1, and the collected samples are listed in Additional file 1 : Table S1. The specimens examined were deposited in the National Natural History Museum of Paris (MNHN). Muscle tissue samples excised from the specimens for genetic studies were preserved in $95 \%$ ethanol and stored at $-20^{\circ} \mathrm{C}$ in the Marine Biodiversity and Phylogenomics laboratory at the Institute of Oceanography, National Taiwan University, Taipei with tissue identification numbers from WIO 001 to WIO 055 (Additional file 1 : Table S1).

Identification and methods for taking counts and measurements of the specimen generally followed Hensley (1997) and Quéro et al. (1988) for the pleuronectiform fishes. All other specimens were identified according to the following taxonomic references: Fischer and Bianchi (1984) (most fishes); Nielsen $(1969,2002)$ and Nielsen et al. (1999) (Ophidiiformes); Cohen et al. (1990) (Macrouridae).

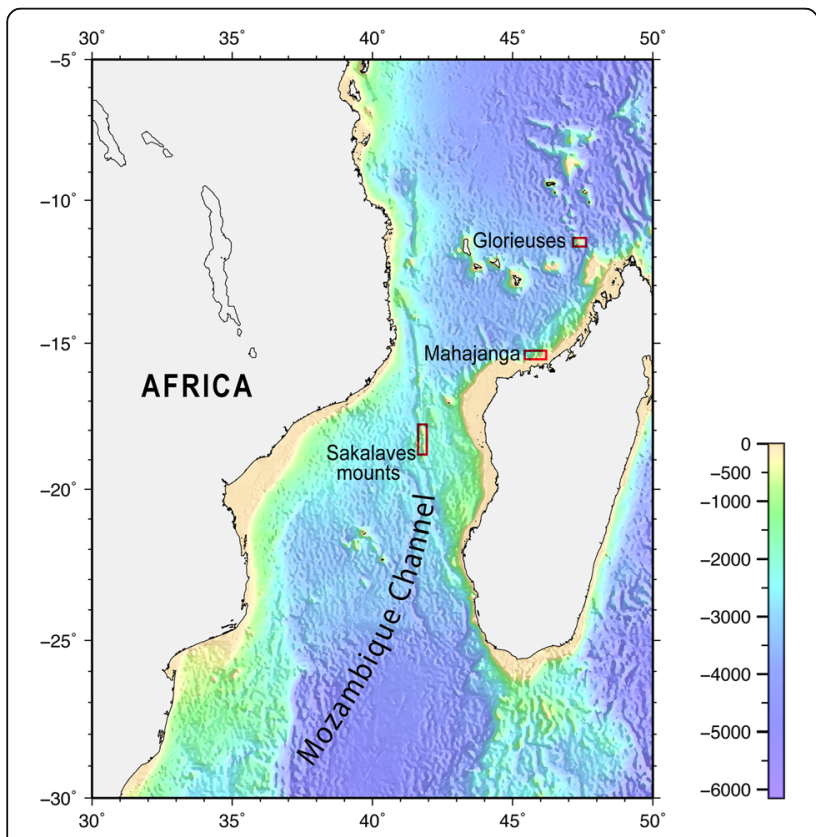

Fig. 1 Bathymetric map of the southwest Indian Ocean region indicating the three explored zones (red boxes) where the specimens examined in this study were collected. Depths are in meters
Whole genomic DNA was extracted from the tissue sample (WIO 041) of the $P$. colorata specimen using an automated extractor: LabTurbo 48 Compact System and LGD 480-500 kits (Taigene Biosciences Corp.) following the manufacturer's protocol. A fragment of the mitochondrial protein-coding gene cytochrome oxidase subunit I (COI) was amplified and sequenced for this study. Protocols for collecting molecular data follow those outlined in Ward et al. (2005). Six available $C O I$ sequences from two congeneric species $(P$. natalensis $[n=5]$ and $P$. hawaiiensis $[n=1])$ were retrieved from Genbank and compared with our obtained sequence. The sequence alignment was conducted manually using Se-Al v2.0a11 (Rambaut, 2002). The variable nucleotide sites and genetic distance (uncorrected pairwise $p$-distance) among sequences and were calculated using PAUP* (Swofford, 2002).

\section{Results}

A total of 55 collected samples were examined. Among them, 49 specimens belong to the 15 following recognized teleost species: Coloconger raniceps Alcock, 1889 (Colocongridae) $(n=6)$, Coloconger scholesi Chan, 1967 (Colocongridae) $(n=1)$, Hoplostethus melanopus (Weber, 1913) (Trachichthyidae) $(n=3), \quad$ Nezumia semiquincunciata (Alcock, 1889) (Macrouridae) $(n=3)$, Ventrifossa johnboborum Iwamoto, 1982 (Macrouridae) $(n=2)$, Lophiodes triradiatus (Lloyd, 1909) (Lophiidae) $(n=1)$, Neoscopelus macrolepidotus Johnson, 1863 (Neoscopelidae) $(n=20)$, Aldrovandia affinis (Günther, 1877) (Halosauridae) $(n=1)$, Aldrovandia phalacra (Vaillant, 1888) (Halosauridae) $(n=1)$, Barathronus diaphanus Brauer, 1906 (Aphyonidae) $(n=1)$, Monomitopus conjugator (Alcock, 1896) (Ophidiidae) $(n=2), \quad$ Neobythites somaliaensis Nielsen, 1995 (Ophidiidae) $(n=3)$, Pentaceros capensis Cuvier, 1829 (Pentacerotidae) $(n=1)$, Poecilopsetta colorata (Poecilopsettidae) $(n=1)$, and Paratriacanthodes retrospinis Fowler, 1934 (Triacanthodidae) $(n=3)$. Six other specimens can only be identified to the genus Symphurus (Cynoglossidae) in two morpho-types ( $n=4$ and 2, respectively) based on the available keys of the species identification. Among the identified species, all expect one (described below) have been recorded in the western Indian Ocean.

\section{Poecilopsetta colorata Günther, 1880, new record (Fig. 2)}

\section{Material examined}

MNHN2016-0180, one specimen, Sakalaves mounts (Fig. 1), $18^{\circ} 0.08589^{\prime} \mathrm{S} 41^{\circ} 46.32208^{\prime} \mathrm{E}, 375 \mathrm{~m}$ depth, R/V Atalante, NIWA seamount sledge, Station MOZ1_DN5 (Table 1), $100 \mathrm{~mm}$ standard length (SL), $44.3 \mathrm{~mm}$ body depth, $25.3 \mathrm{~mm}$ head length, $7.9 \mathrm{~mm}$ upper-jaw length, lateral line scales: ca. 102-105, dorsal soft fin rays: 58, 
Table 1 Information of the operations during the campaign of PAMELA-MOZ01

\begin{tabular}{|c|c|c|c|c|c|c|}
\hline Code of operation & Date & Zone & Latitude & Longitude & Type of operation & Depth $(\mathrm{m})$ \\
\hline MOZ1_DW1 & $28 / 09 / 2014$ & Glorieuses & $11^{\circ} 22.75604^{\prime S S}$ & $47^{\circ} 16.40977^{\prime} E$ & Warén dredge & 789 \\
\hline MOZ1_CP1 & $4 / 10 / 2014$ & Mahajanga & $15^{\circ} 21.46148^{\prime} \mathrm{S}$ & $45^{\circ} 59.28908^{\prime} \mathrm{E}$ & Beam trawl & 722 \\
\hline MOZ1_CP2 & $8 / 10 / 2014$ & Mahajanga & $15^{\circ} 21.72712^{\prime} \mathrm{S}$ & $45^{\circ} 57.65218^{\prime} \mathrm{E}$ & Beam trawl & 869 \\
\hline MOZ1_CP3 & $8 / 10 / 2014$ & Mahajanga & $15^{\circ} 21.71867^{\prime} \mathrm{S}$ & $45^{\circ} 57.52781^{\prime} \mathrm{E}$ & Beam trawl & 971 \\
\hline MOZ1_CP4 & $9 / 10 / 2014$ & Mahajanga & $15^{\circ} 31.00558^{\prime S}$ & $45^{\circ} 41.95738^{\prime} E$ & Beam trawl & 806 \\
\hline MOZ1_DN4 & $14 / 10 / 2014$ & Sakalaves mounts & $18^{\circ} 0.07689^{\prime} S$ & $41^{\circ} 46.31995^{\prime} \mathrm{E}$ & NIWA seamount sledge & 376 \\
\hline MOZ1_DW4 & $14 / 10 / 2014$ & Sakalaves mounts & $18^{\circ} 0.06847^{\prime} S$ & $41^{\circ} 46.3343^{\prime} \mathrm{E}$ & Warén dredge & 376 \\
\hline MOZ1_DN5 & $14 / 10 / 2014$ & Sakalaves mounts & $18^{\circ} 0.08589^{\prime} \mathrm{S}$ & $41^{\circ} 46.32208^{\prime} \mathrm{E}$ & NIWA seamount sledge & 375 \\
\hline
\end{tabular}

anal soft fin rays: 48 , pectoral fin rays: 10 (8 on blind side), pelvic fin rays: 6 , number of nucleotides of the obtained COI sequence (Genbank accession number: KX611099): 648.

\section{Diagnosis}

The counts of dorsal and anal fin rays and lateral line scales are considered as key features for diagnosing species of Poecilopsetta (Hoshino et al., 2001; Kawai et al., 2010). These counts in our examined specimen were 58, 48, and ca. 102-105, which fall into the ranges of the three characters for $P$. colorata (55-62, 46-53, and 90-124) and P. praelonga (57-65, 45-55, and 91-113) as being described in Kawai et al. (2010). The former species can be easily distinguished from the latter in having a deeper body (body depth 1.9 to 2.6 times in SL vs. body depth 3.8 to 4 times in SL) and a longer upper-jaw (upper-jaw length 3 to 3.5 times in head length vs. upper-jaw length 3.6 to 3.7 times in head length) (Hensley, 1997). Our specimen was diagnosed with body depth 2.3 times in SL and upper-jaw length 3.2 times in head length. All these characteristics combined together indicate our specimen is $P$. colorata.

From the aligned COI sequences for the samples of the three Poecilopsetta species included in this study (see methods), 28 variable sites were observed along the 684-bp long sequenced fragments (Fig. 3). This represents $2.76 \%$ interspecific nucleotide divergence on average (evaluated by uncorrected pairwise p-distance). The nucleotide divergence among five $P$. natalensis samples collected from South Africa $(n=4)$ and from the South China Sea $(n=1)$ was estimated to be $0.64 \%$. Diagnostic nucleotides of $P$. colorata to $P$. natalensis are site numbers 046, 126, 225, 252, 315, 360, 420, 444, 477, $510,513,565,612,618,621$, and 639. Diagnostic nucleotides of $P$. colorata to $P$. hawaiiensis are site numbers 210, 225, 313, 315, 369, 390, 477, 505, 510, 513, 537, $549,561,594,603,618,621$, and 678 (Fig. 3). The available genetic data further confirm that our specimen is distinguishable from the co-occurring species from the region, $P$. natalensis.

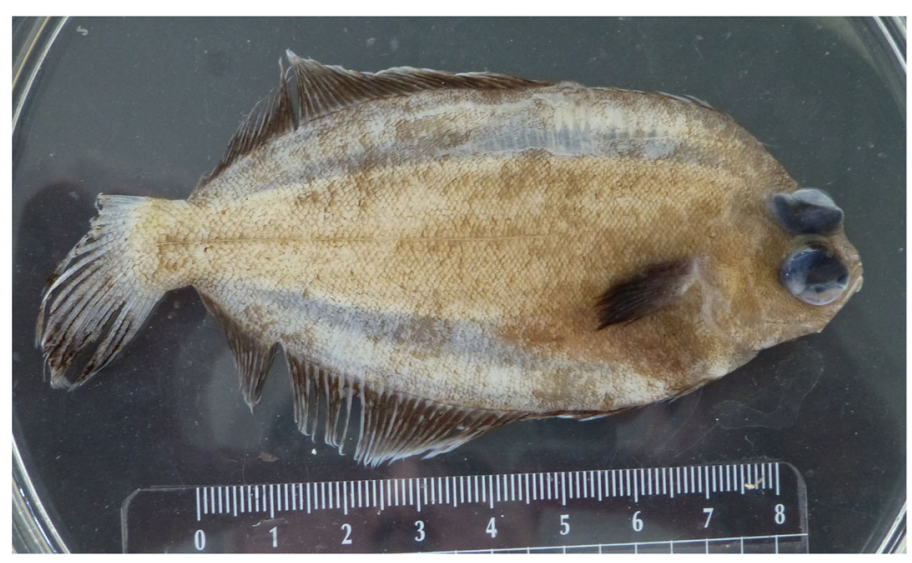

Fig. 2 Poecilopsetta colorata Günther, 1880, MNHN2016-0180 from the Sakalaves seamount, collected on Oct. 14, 2014. Standard length 100 mm 


\begin{tabular}{|c|c|c|c|c|c|c|c|c|c|c|c|c|c|c|c|c|c|c|c|c|c|c|c|c|c|c|c|c|}
\hline \multirow{4}{*}{$\begin{array}{l}\text { Species } \\
\text { Samples, locality, GenBank no. }\end{array}$} & \multicolumn{28}{|c|}{ Nucleotide position } \\
\hline & 0 & 1 & 2 & 2 & 2 & 3 & 3 & 3 & 3 & 3 & 4 & 4 & 4 & 5 & 5 & 5 & 5 & 5 & 5 & 5 & 5 & 6 & 6 & 6 & 6 & 6 & 6 & 6 \\
\hline & 4 & 2 & 1 & 2 & 5 & 1 & 1 & 6 & 6 & 9 & 2 & 4 & 7 & 0 & 1 & 1 & 3 & 4 & 6 & 6 & 9 & 0 & 1 & 1 & 2 & 3 & 7 & 7 \\
\hline & 6 & 6 & 0 & 5 & 2 & 3 & 5 & 0 & 9 & 0 & 0 & 4 & 7 & 5 & 0 & 3 & 7 & 9 & 1 & 5 & 4 & 3 & 2 & 8 & 1 & 9 & 5 & 8 \\
\hline \multicolumn{29}{|l|}{ P. natalensis } \\
\hline HQ945815, South Africa & ? & c & A & $\mathrm{T}$ & G & C & A & $\mathrm{T}$ & G & C & A & $\mathrm{T}$ & G & A & $\mathrm{T}$ & A & $\mathrm{T}$ & A & C & C & C & C & G & C & A & $\mathrm{T}$ & A & $\mathrm{T}$ \\
\hline HQ945811, South Africa & ? & . & . & . & . & . & . & . & . & . & . & . & . & . & . & . & . & . & . & . & . & . & . & . & . & . & . & . \\
\hline GU804926, South Africa & $?$ & & 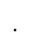 & . & . & . & . & . & . & . & . & . & . & . & & . & . & . & . & . & . & . & & . & . & . & G & \\
\hline GU804911, South Africa & ? & . & . & . & . & . & . & . & . & . & . & . & . & . & . & . & . & . & . & . & . & . & . & . & . & . & . & . \\
\hline JQ700099, South China Sea & C & . & . & . & . & . & . & . & . & . & . & . & . & . & . & . & . & . & . & . & . & . & . & . & . & . & . & . \\
\hline \multicolumn{29}{|l|}{ P. colorata } \\
\hline KX611099, Mozambique Channel & $\mathrm{T}$ & $\mathrm{T}$ & & C & A &. & G & C & . & . & G & C & A & & C & G & . & . & . & $\mathrm{T}$ & . & . & $\mathrm{T}$ & $\mathrm{T}$ & G & C & & \\
\hline P. hawaiiensis & & & & & & & & & & & & & & & & & & & & & & & & & & & & \\
\hline DQ521023, Hawaii & ? & $\mathrm{T}$ & G & & A & $\mathrm{T}$ & & C & A & $\mathrm{T}$ & G & C & & G & & & C & G & $\mathrm{T}$ & $\mathrm{T}$ & $\mathrm{T}$ & $\mathrm{T}$ & $\mathrm{T}$ & & & C & & A \\
\hline
\end{tabular}

Fig. 3 Polymorphic nucleotide sites at the cytochrome c oxidase subunit-l locus in three Poecilopsetta species. Numeration of nucleotide sites starts from first nucleotide of the corresponding gene. Genbank accession numbers of the sequences are given

\section{Remarks}

Based on the new record in this study, the distribution of the species extends to the western Indian Ocean from its previously reported area. The four other teleost fish species also collected from the same seamounts are: Neobythites somaliaensis (Ophidiidae), Pentaceros capensis (Pentacerotidae), Symphurus sp. 2 (Cynoglossidae), and Paratriacanthodes retrospinis (Triacanthodidae) (Additional file 1: Table S1). N. somaliaensis is an uncommon ophidiid species that was described based on specimens collected on the upper continental slope in the Gulf of Aden (Nielsen, 1995). The present record in the Mozambique Channel is new. This species is most similar to the common Neobythites species, N. analis Barnard 1927, from this region (Nielsen et al. 1999; 2002); it differs from $N$. analis by the distal parts of both dorsal and anal fins being black (Fig. 4).

\section{Discussion}

Although some flatfishes including poecilopsettids have large and presumably long-lived larvae that could enhance the probability of achieving long-distance dispersal over large areas (Evseenko, 2000), widespread species crossing two oceans are rare in poecilopsettids (Munroe, 2005). In
Poecilopsetta, P. colorata and P. praelonga are the only two species known to have a wide distribution ranging from the eastern Indian Ocean to the western Pacific Ocean (Quéro et al., 1988; Hensley, 1997). The record of $P$. colorata in the western Indian Ocean presented here confirms a wide and an extended distribution for this poorly known deep-sea species. The African righteye flounder, $P$. natalensis, also occurs in the western Indian Ocean. The extension of its distribution into the western Pacific has been suspected because of an unconfirmed record reported in Taiwan (Hensley, 1997). In this study, one of our compared COI sequences of $P$. natalensis was from the South China Sea (Fig. 3), confirming the presence of this species in the western Pacific Ocean. It is worthy to mention that the genetic distance between this sample of P. natalensis and others from South Africa is very low, from zero to $0.64 \%$ of nucleotide divergence (corresponding to a single nucleotide difference), despite the large distance between the two sampling sites (Fig. 3). A genetic break corresponding to the geology that separates the Indian population from the Pacific one is often present in widespread marine Indo-West Pacific species (Borsa et al., 2016); it was not observed in P. natalensis.

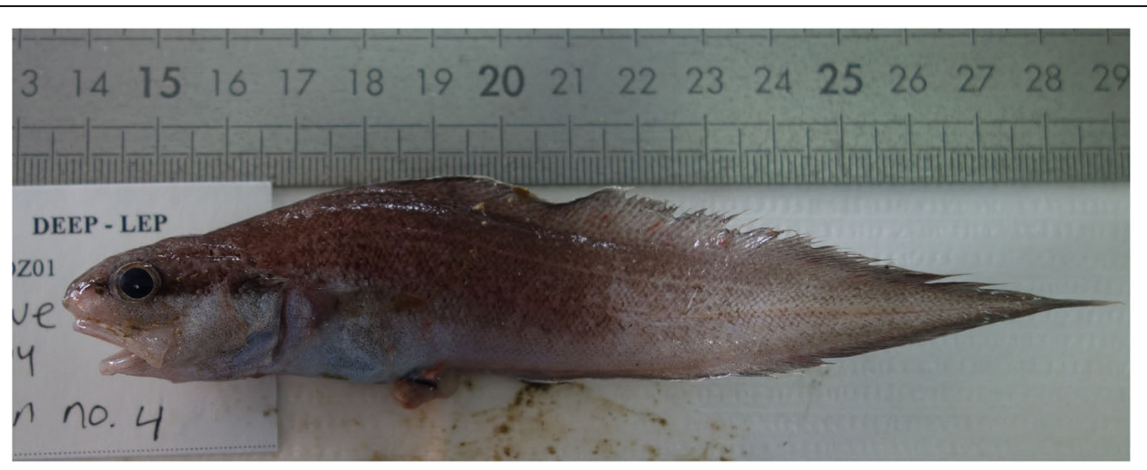

Fig. 4 Neobythites somaliaensis Nielsen, 1995, MNHN2016-0176 from the Sakalaves seamount, collected on Oct. 14, 2014. Standard length 140 mm 


\section{Conclusions}

The first record of $P$. colorata from the Sakalaves seamounts on the southern Davie Ridge in the Mozambique Channel is reported. This record extends the known range of $P$. colorata to the western Indian Ocean. The occurrences of this species elsewhere include the Bay of Bengal to the South China Sea and Indonesia. The individuals are known to live at depths of 214 to $800 \mathrm{~m} \mathrm{(375} \mathrm{m} \mathrm{in} \mathrm{this}$ study). The COI sequence for the collected $P$. colorata specimen is also provided as a genetic reference. Its availability can permit DNA barcoding work for fish identification purposes and future systematic or other advanced research such as biogeography or studying the evolutionary dynamics of species across the oceans.

\section{Additional file}

Additional file 1: Table S1. List of the samples collected during the cruise (campaign: PAMELA-MOZO1) and examined in this study. CP: Beam trawl. DN: NIWA sledge. DW: Warén dredge. (DOCX 27 kb)

\section{Abbreviations}

RN: Research vessel; SL: Standard length; COI: Cytochrome c oxidase subunit-l; DNA: Deoxyribonucleic acid; Bp: Base pair

\section{Acknowledgements}

Our gratitude goes to the crews of the RN Atalante and participants of the oceanographic cruise (campaign: PAMELA-MOZ01, PI: K. Olu, part of the Mozambique 2014 study) involved in organizing the survey and the capture of the samples. The Mozambique 2014 study is co-funded by TOTAL and Ifremer as part of the PAMELA (Passive Margin Exploration Laboratories) scientific project. The PAMELA project is a scientific project leaded by Ifremer and TOTAL in collaboration with Université de Bretagne Occidentale, Université Rennes 1, Université Pierre and Marie Curie, CNRS and IFPEN. We are grateful to Stephan Jorry as PI of the Mozambique 2014 study and for providing bathymetric data of the sampling sites (Ptolemée cruise: http://dx.doi.org/10.17600/14000900). We thank Anne Basseres (TOTAL, co-PI of Ecosystem studies in Pamela), Philippe Bourges, Jean-Nöel Ferry (TOTAL) and Jean-Fançois Bourillet as PIs of PAMELA for the management of the project. We acknowledge Inge van den Beld for her help onboard for biological samples, Philippe Noël for its help with sampling gears, J.-F. Barazer and M. Clark for the drawings and advices of the Warén dredges and Niwa seamount sledge. We thank Laure Corbari for their involvement in the collaboration between WJC and Ifremer. We are grateful to L.-H. Chen for improving artwork, C.-Y. Chang who helped us to prepare Fig. 1 using Generate Mapping Tool (GMT), and M. A. Campbell for language editing.

\section{Funding}

Ministry of Science \& Technology, Taiwan (MOST 102-2923-B-002 -001 -MY3) to WJC.

\section{Availability of data and material}

Sequence data are available in GenBank from National Center for Biotechnology Information; specimens are available from National Museum of Natural History, Paris, France.

\section{Authors' contributions}

WJC contributed to the conception and design of the work, analyzed, interpreted the data, and wrote the paper; JNC collected the data and wrote the paper; JEP collected and managed the samples; KO led the cruise of sample collection and revised the paper. All authors read and approved the final manuscript.

\section{Consent for publication}

Not applicable.

\section{Competing interests}

The authors declare that they have no competing interests.

\section{Ethics approval and consent to participate}

The research was performed at National Taiwan University in accordance with the National Taiwan University's guidelines regarding animal research. As this project had no experiment involved live fishes (conducted based the preserved specimens from Museum), no ethics statement was required.

\section{Author details}

${ }^{1}$ Institute of Oceanography, National Taiwan University, No.1 Sec. 4 Roosevelt Road, Taipei 10617, Taiwan. ²Département REM/EEP/Laboratoire Environnement Profond, IFREMER/Centre de Bretagne, Institut Carnot EDROME, 29280 Plouzané, France.

Received: 26 June 2016 Accepted: 2 September 2016

Published online: 01 October 2016

\section{References}

Borsa P, Durand JD, Chen W-J, Nicolas H, Muths D, Mou-Tham G, Kulbicki M. Comparative phylogeography of the western Indian Ocean reef fauna. Acta Oecol. 2016;72:72-86

Cohen DM, Inada T, Iwamoto T, Scialabba N. Gadiform fishes of the world (Order Gadiformes). An annotated and illustrated catalogue of cods, hakes, grenadiers and other gadiform fishes known to date. FAO Fish Synop Rome. 1990;125(10):90-310.

Evseenko SA. Family Achiropsettidae and its position in the taxonomic and ecological classifications of Pleuronectiformes. J Ichthyol. 2000;40:S110-38.

Evseenko SA. Family Pleuronectidae Cuvier 1816 - righteye flounders. Cali Acad Sci Annotated Checklists of Fishes. 2004:37:1-37.

Fischer W and Bianchi G. editors. FAO species identification sheets for fishery purposes. Western Indian Ocean (Fishing Area 51). FAO Rome. 1984; Vol.2-6.

Foroshchuk VP, Fedorov W. Poecilopsetta normani - a new species of flounder (Pleuronectidae) from the Saya de Malha Bank, Indian Ocean. J Ichthyol. 1992;32(7):37-44

Guibord AC, Chapleau F. Poecilopsetta dorsialta: a new species of Poecilopsettidae (Pleuronectiformes) from the Pacific Ocean. Copeia. 2001; 2001(4):1081-6.

Guibord AC, Chapleau F. Poecilopsetta megalepis Fowler 1934, un synonyme junior de Poecilopsetta plinthus (Jordan and Starks, 1904) (Pleuronectiformes: Poecilopsettidae). Cybium. 2002;26:135-9.

Hensley DA. Pleuronectidae. Righteye flounders. In: Carpenter KE, Niem V, editors. FAO Identification Guide for Fishery Purposes, vol. 6. Rome: The Western Central Pacific; 1997. p. 3863-77.

Hoshino K. Redescription of a rare flounder, Poecilopsetta inermis (Breder) (Pleuronectiformes: Pleuronectidae: Poecilopsettinae), a senior synonym of $P$. albomarginata Reid, from the Caribbean Sea and tropical western Atlantic. Ichthyol Res. 2000;47:95-100.

Hoshino K, Amaoka K, Last P. A new dextral flounder, Poecilopsetta macrocephala (Pisces: Pleuronectiformes: Poecilopsettidae), from northwestern Australia. Species Divers. 2001;6:73-81.

Kawai T, Amaoka K. A new righteye flounder, Poecilopsetta pectoralis (Pleuronectiformes: Poecilopsettidae), from New Caledonia. Ichthyol Res. 2006;:53:264-8.

Kawai T, Amaoka K, Séret B. A new righteye flounder, Poecilopsetta multiradiata (Teleostei: Pleuronectiformes: Poecilopsettidae), from New Zealand and New Caledonia (South-West Pacific). Ichthyol Res. 2010;57(2):193-8.

Munroe TA. Distributions and Biogeography. In: Gibson RN, Nash RDM, Geffen AJ, Van der Veer HW, editors. Flatfishes: Biology and Exploitation. Oxford, UK: Blackwell Science Ltd; 2005. doi:10.1002/9780470995259.ch3.

Munroe TA. Chapter 2. Systematic diversity of the Pleuronectiformes. In: Gibson RN, Nash RM, Geffen AJ, Van der Veer HW, editors. Flatfishes Biology and exploitation 2nd edition. Fish and Aquatic Resources (Series 16). UK: Wiley; 2015. p. 13-51.

Nelson JS. Fishes of the World, fourth ed. New York: Wiley; 2006. p. 442-51.

Nielsen JG. Systematics and biology of the Aphyonides (Pisces, Ophidiodea). Galathea Report. 1969;10:7-90. Pls.1-4.

Nielsen JG. A review of the species of the genus Neobythites (Pisces: Ophidiidae) from the western Indian Ocean, with description of seven new species. Ichth Bull. 1995;62:1-19. 
Nielsen JG. Revision of the Indo-Pacific species of Neobythites (Teleostei, Ophidiidae), with 15 new species. Galathea Report. 2002;19:5-104.

Nielsen JG, Cohen DM, Markle DF, Robins CR. Ophidiiform fishes of the world (Order Ophidiiformes). An annotated and illustrated catalogue of pearlfishes, cusk-eels, brotulas and other ophidiiform fishes known to date. FAO Fish Synop Rome. 1999;125(18):76-87.

Olu K. PAMELA-MOZ01 cruise. RV L'Atalante. 2014. doi: http://dx.doi.org/10.17600/ 14001000.

Quéro JC, Hensley DA, Maugé AL. Pleuronectidae de lî̂le de la Réunion et de Madagascar. I. Poecilopsetta. Cybium. 1988;12:2-11.

Rambaut A. Sequence Alignment Editor Version 2.0a11. 2002. http://tree.bio.ed.ac. uk/software/seal/

Sakamoto K. Interrelationships of the family Pleuronectidae (Pisces, Pleuronectiformes). Mem Fac Fish Hokkaido Univ. 1984;31:95-215. Swofford DL. PAUP*: Phylogenetic Analysis Using Parsimony (* and Other Methods), Version 4. Sunderland, Massachusetts: Sinauer Associates; 2002. Ward RD, Zemlak TS, Innes BH, Last PR, Hebert PDN. Barcoding Australia's fish species. Phil Trans R Soc B. 2005;360:1847-57.

Submit your next manuscript to BioMed Central and we will help you at every step:

- We accept pre-submission inquiries

- Our selector tool helps you to find the most relevant journal

- We provide round the clock customer support

- Convenient online submission

- Thorough peer review

- Inclusion in PubMed and all major indexing services

- Maximum visibility for your research

Submit your manuscript at www.biomedcentral.com/submit
Biomed Central 